\title{
Erratum to: The UBC-40 Urothelial Bladder Cancer Cell Line Index: a genomic resource for functional studies
}

\author{
Julie Earl ${ }^{1,2}$, Daniel Rico ${ }^{3}$, Enrique Carrillo-de-Santa-Pau', Benjamín Rodríguez-Santiago ${ }^{4,6}$, Marinela Méndez-Pertuz ${ }^{1}$ \\ Herbert Auer ${ }^{7}$, Gonzalo Gómez ${ }^{8}$, H. Barton Grossman ${ }^{9}$, David G. Pisano ${ }^{8}$, Wolfgang A. Schulz ${ }^{10}$, \\ Luis A. Pérez-Jurado ${ }^{5,6}$, Alfredo Carrato2 ${ }^{2}$ Dan Theodorescu ${ }^{11}$, Stephen Chanock ${ }^{12}$, Alfonso Valencia ${ }^{3}$ \\ and Francisco X. Real ${ }^{1,5^{*}}$
}

Keywords: Urothelial bladder cancer, Cell line, Genomics, Mutation, Oncogene, Tumor suppressor

Following the publication of our recent article in BMC Genomics [1] a number of aspects were called to our attention. We have carefully reviewed the experiments reported in this manuscript, as well as additional data from our laboratories, and would like to make the following points:

1. SW-850, included in our paper as a bladder cancer cell line, has been reported by several authors to be a pancreatic cancer cell line [2-5]. This is unlikely to be the case given that most pancreatic cancers are $K R A S$-mutant and both our analysis and a previous publication [5] indicate that the cells used are KRASwild type. However, given the controversy we recommend that these cells are not be used as bladder cancer models.

2. The Materials and Methods section of our paper indicated that the following cell lines were obtained from ATCC: 253 J, 575A, 639 V, JON, MGH-U4, SW800, SW-1710, VM-CUB-2. However, these cultures have never been distributed by the ATCC. Therefore, they are available from us if other investigators are interested in using them.

3. It has been reported that UM-UC-2 is a T24 contaminant (http://www.ncbi.nlm.nih.gov/biosample/

\footnotetext{
* Correspondence: preal@cnio.es

${ }^{1}$ Epithelial Carcinogenesis Group, F BBVA Cancer Cell Biology Programme, CNIO (Spanish National Cancer Research Centre), Melchor Fernández

Almagro, 3, 28029 Madrid, Spain

${ }^{5}$ Departament de Ciències Experimentals i de la Salut, Universitat Pompeu

Fabra, Barcelona, Spain

Full list of author information is available at the end of the article
}

SAMN03151953,http://web.expasy.org/cellosaurus/ CVCL_8155, http://iclac.org/wp-content/uploads/ Cross-Contaminations-v7_2.pdf). We have used fingerprinting analysis to confirm this fact and the genetic identity of the cells/DNAs used in our experiments (Table 1 ).

4. It has been reported that VM-CUB-3 is a VM-CUB-1 contaminant (http://iclac.org/wp-content/uploads/ Cross-Contaminations-v7_2.pdf, http://www.ncbi.nlm.nih.gov/biosample/3152040, http://web.expasy.org/cellosaurus/CVCL_9830). Nevertheless, our data indicate that the two cultures we used as VM-CUB- 1 and VMCUB-3 are distinct at the genomic level. Furthermore, as shown in Table 1, fingerprinting analysis clearly indicates that VM-CUB-1, VM-CUB-2, and VM-CUB-3 are different from each other. The origin of the DNA/ cells in our paper was as indicated in the Material and Methods section and, therefore, investigators interested in these cells could directly address the corresponding co-authors.

In the last few years there has been much emphasis on the need to accurately designate, identify, and characterize cancer cell lines as they are precious tools for cell biology studies $[6,7]$. It is with this aim that we wish to make these comments and clarifications related to our recently published work. 
Table 1 SNP fingerprint analysis of the bladder cancer cell lines suffering from an "identity crisis"

\begin{tabular}{|c|c|c|c|c|c|c|c|c|c|c|}
\hline Cell Line & Comments & D5S818 & D13S317 & D7S820 & D16S539 & WWA & TH01 & AM & TPOX & CSF1PO \\
\hline VM- CUB-1 p29 & & 11 & 10 & 8,11 & 11,12 & 18,19 & 9 & $x$ & 8 & 11 \\
\hline VM-CUB-2 p112 & & 11,13 & 12 & 8 & 9 & 14 & 7 & $X, Y$ & 8,12 & 11,12 \\
\hline VM-CUB-3 p65 & & 11 & 9,12 & 8,9 & 12 & 16 & 9.3 & $x$ & 8 & 12 \\
\hline UM-UC-2 p264 & $\begin{array}{l}\text { DNA fingerprinting } \\
\text { data, same as T24 }\end{array}$ & 10,12 & 10,12 & 10,11 & 9 & 17 & 6 & $x$ & 8,11 & 10,12 \\
\hline T24 p8 & ATCC & 10,12 & 12 & 10,11 & 9 & 17,19 & 6 & $x$ & 8,11 & 10,12 \\
\hline
\end{tabular}

$P$ passage

\section{Competing interests}

The authors declare no competing financial interests.

\section{Author details}

${ }^{1}$ Epithelial Carcinogenesis Group, F BBVA Cancer Cell Biology Programme, CNIO (Spanish National Cancer Research Centre), Melchor Fernández Almagro, 3, 28029 Madrid, Spain. ²Servicio de Oncología Médica, Hospital Ramón y Cajal, Madrid, Spain. ${ }^{3}$ Structural Computational Biology Group, Structural Biology and Biocomputing Programme, CNIO (Spanish National Cancer Research Centre), Madrid, Spain. ${ }^{4}$ Quantitative Genomic Medicine Laboratory, qGenomics, Barcelona, Spain. ${ }^{5}$ Departament de Ciències Experimentals i de la Salut, Universitat Pompeu Fabra, Barcelona, Spain. ${ }^{6}$ Centro de Investigación Biomédica en Red de Enfermedades Raras (CIBERER), Barcelona, Spain. IInstitut de Recerca Biomèdica de Barcelona, Parc Científic de Barcelona, Barcelona, Spain. ${ }^{8}$ Bioinformatics Unit, Structural Biology and Biocomputing Programme, CNIO (Spanish National Cancer Research Centre), Madrid, Spain. ${ }^{9}$ Department of Urology, MD Anderson Cancer Center, Houston, TX, USA. ${ }^{10}$ Department of Urology, Heinrich-Heine-University, Düsseldorf, Germany. ${ }^{11}$ University of Colorado Comprehensive Cancer Center, Aurora, CO 80045, USA. ${ }^{12}$ Translational Genomics Laboratory, Division of Cancer Epidemiology and Genetics, National Cancer Institute, Bethesda, USA.

Received: 18 November 2015 Accepted: 18 November 2015

Published online: 30 November 2015

\section{References}

1. Earl J, Rico D, Carrillo-de-Santa-Pau E, Rodríguez-Santiago B, Méndez M, Auer $\mathrm{H}$, et al. The UBC-40 Urothelial Bladder Cancer Cell Line Index: a genomic resource for functional studies. BMC Genomics. 2015;16:403.

2. Fogh J, Fogh JM, Orfeo T. One hundred and twenty-seven cultured human tumor cell lines producing tumors in nude mice. J Natl Cancer Inst. 1977; 59(1):221-6.

3. Fogh J, Wright WC, Loveless JD. Absence of HeLa cell contamination in 169 cell lines derived from human tumors. J Natl Cancer Inst. 1977;58(2):209-14.

4. Kalthoff H, Schmiegel W, Roeder C, Kasche D, Schmidt A, Lauer G, et al. p53 and K-RAS alterations in pancreatic epithelial cell lesions. Oncogene. 1993; 8(2):289-98.

5. Müller C, Bockhorn AG, Klusmeier S, Kiehl M, Roeder C, Kalthoff H, et al. Lovastatin inhibits proliferation of pancreatic cancer cell lines with mutant as well as with wild-type K-ras oncogene but has different effects on protein phosphorylation and induction of apoptosis. Int J Oncol. 1998;12(3):717-23.

6. Freedman LP, Gibson MC, Ethier SP, Soule HR, Neve RM, Reid YA. Reproducibility: changing the policies and culture of cell line authentication. Nat Methods. 2015;12(6):493-7.

7. Yu M, Selvaraj SK, Liang-Chu MM, Aghajani S, Busse M, Yuan J, et al. A resource for cell line authentication, annotation and quality control. Nature. 2015;520(7547):307-11.

\section{Submit your next manuscript to BioMed Central} and we will help you at every step:

- We accept pre-submission inquiries

- Our selector tool helps you to find the most relevant journal

- We provide round the clock customer support

- Convenient online submission

- Thorough peer review

- Inclusion in PubMed and all major indexing services

- Maximum visibility for your research

Submit your manuscript at www.biomedcentral.com/submit
C Biomed Central 